\title{
Strategi Pengendalian Dampak Sosial dan Ekonomi Pembangunan Pusat Perbelanjaan Modern: Studi Kasus di Kawasan Blok M Jakarta
}

\author{
Noveri Maulana* \\ Sekolah Tinggi Manajemen PPM \\ Joshua Michael P. Hutagalung \\ Sekolah Tinggi Manajemen PPM \\ *noverimaulana@gmail.com /nvr@ppm-manajemen.ac.id
}

\begin{abstract}
Abstrak
Pusat perbelanjaan modern bukan saja menjadi tempat untuk menjual produk kebutuhan masyarakat, namun juga menjadi sebuah tempat yang memenuhi kebutuhan lainnya dalam kelompok sekunder dan tersier. Studi ini menelaah dampak sosial dan ekonomi salah satu pusat perbelanjaan di kawasan Blok M Jakarta terhadap masyarakat yang berada di kawasan Kebayoran Baru, Jakarta Selatan. Studi kualitatif ini menggunakan survey, observasi, dan indepth interview untuk memperoleh data. Seluruh data dianalisis dengan pendekatan content \& context analysis, kemudian diformulasi ke dalam TOWS Matriks. Hasil analisis memberikan 4 (empat) strategi sebagai rekomendasi bagi manajemen untuk mengelola dampak sosial dan ekonomi keberadaan pusat perbelanjaan di tengah masyarakat. Pertama, optimalisasi hubungan dengan tokoh masyarakat dan aparat pemerintahan. Kedua ialah penanganan ruang publik dan fasilitas umum yang lebih serius dari manajemen pusat perbelanjaan. Ketiga, pembinaan masyarakat terkait kewirausahaan, UMKM, dan aktivitas di pasar tradisional juga perlu melibatkan manajemen salah satunya melalui kegiatan CSR secara berkala. Dan terakhir ialah terkait sosialisasi dan komunikasi aktif terhadap masyarakat juga perlu ditingkatkan, tidak hanya untuk aktivitas promosi tetapi juga mencakup kegiatan edukasi. Studi ini bisa memberikan kerangka analisis bagi penelitian sejenis di kemudian hari.
\end{abstract}

Kata Kunci: SWOT, TOWS Matriks, AMDAL, Strategi CSR, Dampak Sosial Ekonomi, Pusat Perbelanjaan

\section{Pendahuluan}

Pembangunan pusat perbelanjaan modern menjadi sebuah fenomena yang beriringan dengan kemajuan peradaban manusia. Pusat perbelanjaan modern adalah bentuk jawaban dari tingkat kebutuhan manusia yang terus berkembang pesat, terus meningkat, dan semakin beragam. Sejatinya, pusat perbelanjaan telah berkembang sejak dulu dengan keberadaan pasar tradisional yang menyediakan berbagai kebutuhan pokok manusia. Namun, semakin waktu berlalu, kebutuhan manusia yang semakin beragam itu seringkali sulit dipenuhi karena keterbatasan akses, sarana, dan prasarana yang memadai (Farchan, 2016; Taylor et al., 2003). Konsep inilah yang menginspirasi para pelaku bisnis untuk membangun pusat perbelanjaan modern yang seringkali kita sebut sebagai mall, plaza, atau shopping center. Pusat perbelanjaan modern bukan saja menjadi tempat untuk menjual produk kebutuhan masyarakat, namun juga menjadi sebuah tempat yang memenuhi kebutuhan lainnya dalam kelompok sekunder dan tersier. Bahkan, dalam perspektif yang lebih luas lagi, pusat perbelanjaan tidak 
hanya memenuhi kebutuhan pokok manusia, tapi juga menciptakan kebutuhan-kebutuhan baru manusia masa kini (Dębek, 2015).

Kottler (2011) menjelaskan bahwa dalam ilmu manajemen bisnis, perilaku manusia bisa dipenuhi dalam dua kategori, yaitu need dan want. Kebutuhan (need) merupakan asas utama yang perlu diperhatikan oleh pelaku bisnis dibandingkan sekedar memenuhi keinginan (want). Namun, dalam menyusun strategi bisnis yang baik, seorang pelaku bisnis harus mampu memadukan keinginan manusia yang menjadi kebutuhan (Kotler, 2011). Dalam hal ini, pusat perbelanjaan juga menerapkan prinsip memadukan keinginan dan kebutuhan manusia dalam satu produk yang terintegrasi tersebut. Hal ini menjadi dasar pemikiran bahwa keberadaan mall bukan saja sebagai pemenuhan keinginan manusia, tetapi sudah menjadi kebutuhan yang tak bisa dihindarkan dari kehidupan sehari-hari manusia urban masa kini.

Dampak kehadiran pusat perbelanjaan tidak hanya bisa dilihat dari perannya dalam upaya pemenuhan kebutuhan masyarakat, namun juga cenderung memiliki pengaruh negatif terhadap lingkungan sekitar. Farchan (2010) mengemukakan bahwa pusat perbelanjaan juga berpotensi mematikan bisnis kecil di lingkungan dan juga berkontribusi terhadap kondisi sosial ekonomi masyarakat di sekitar lokasi pembangunan (Farchan, 2016; Maulana, 2017). Hasil penelitian Fakultas Ekonomi Syariah UIN Palu, Aisyah (2015) juga menjelaskan bahwa pembangunan mall akan berdampak negatif bagi pedagang kecil dan UMKM, namun tak dapat dipungkiri, mall juga memberikan manfaat yang sangat besar bagi masyarakat luas di perkotaan. Oleh karena itu, para pelaku bisnis diharapkan mampu memiliki kajian yang baik untuk mengatasi dampak negatif keberadaan bisnis mereka pada lingkungan sekitarnya (Aisyah, 2015).

Hal ini juga menjadi perhatian serius pemerintah dengan mengeluarkan Peraturan Presiden no 112 tahun 2007 Tentang Penataan dan Pembinaan Pasar Tradisional, Pusat Perbelanjaan, dan Toko Modern. Peraturan Presiden tersebut juga dikuatkan dengan Peraturan Menteri Perdagangan RI nomor 70 tahun 2013 tentang Pedoman Penataan dan Pembinaan Pasar Tradisional, Pusat Perbelanjaan, dan Toko Modern. Dalam peraturan tersebut telah dijelaskan secara rinci mengenai kewajiban pelaku bisnis dalam pendirian dan pengelolaan pusat perbelanjaan. Salah satu kewajibannya ialah dengan menyajikan analisis dampak sosial ekonomi atas keberadaan pusat perbelanjaan tersebut terhadap masyarakat sekitar. Analisis harus dibuat sebagai dasar bagi perusahaan untuk merancang strategi kemitraan dan penanggulan masalah potensial yang bisa mempengaruhi kondisi sosial ekonomi masyarakat di sekitar kawasan pusat perbelanjaan.

Oleh karena itu, kajian ini akan menelaah dampak sosial dan ekonomi pusat perbelanjaan modern di kawasan Blok M, daerah Kebayoran Baru, Jakarta Selatan. Selain berisi analisis terhadap kondisi sosial dan ekonomi, kajian ini juga akan memberikan rekomendasi bagi pengelola dan juga pemerintah dalam upaya menangani dampak ekonomi kawasan dan lingkungan sosial masyarakat khususnya di kawasan Blok M, Kebayoran Baru, Jakarta Selaran. Kecamatan Kebayoran Baru merupakan salah satu kecamatan yang termasuk dalam wilayah Kotamadya Jakarta Selatan. Sebagai sebuah kawasan yang diperuntukkan bagi pemukiman, Kebayoran Baru dirancang oleh para arsitek Belanda yang mengedepankan konsep 'garden residence' yang memadukan konsep perumahan dan pertamanan (wikipedia.com). Tidak heran, jika hingga saat ini, kawasan di Kebayoran Baru masih banyak ditumbuhi oleh pohon-pohon besar yang berusia puluhan tahun. Keberadaan pohon ini pulalah yang membuat kawasan Kebayoran Baru lebih asri dan sejuk dibandingkan kawasan Jakarta pada umumnya. Dengan luas total wilayah $12,9 \mathrm{Km}^{2}$ atau setara $9 \%$ dari total luas Kota Jakarta Selatan, Kebayoran Baru menjadi daerah penyangga yang berhubungan langsung dengan kawasan perkantoran dan pusat bisnis di Jakarta, seperti kawasan Sudirman dan Senayan. Hal 
ini tentunya memberi banyak dampak positif dalam pengembangan kawasan Kebayoran Baru, terutama terkait sarana dan prasarana publik, termasuk jalan raya. Akses jalan, transportasi umum, dan prasarana lainnya menjadi andalan kawasan Kebayoran Baru. Tidak heran jika harga tanah di kawasan Kebayoran Baru menjadi cukup tinggi dan terus meningkat setiap tahunnya. Bahkan, harga tanah di kawasan pemukiman Kebayoran Baru juga menyaingi harga tanah di kawasan Menteng yang disebut-sebut sebagai kawasan elit dan perumahan termahal di Jakarta.

Kondisi geografis Kebayoran Baru memang telah didesain sedemikian rupa sejak awal dibangun pada tahun 1960 silam. Beberapa Blok yang menjadi ciri khas Kebayoran Baru telah diidentikkan dengan kegunaannya masing-masing. Misalnya, Blok M diperuntukkan untuk aktivitas bisnis dan perekonomian masyarakat. Oleh Karena itu, sampai saat ini kita masih bisa menyaksikan sebagian besar aktivitas bisnis dan perekonomian masyarakat di kawasan Kebayoran Baru berpusat di sekitar Blok M. Keberadaan pasar dan pusat perbelanjaan menjadi salah satu indikator aktivitas perekonomian masyarakat di kawasan Kebayoran Baru. Berdasarkan data sensus kecamatan pada tahun 2014, terdapat 5 pasar inpres, 3 pasar tradisional, 6 pasar swalayan, 6 mall, 1 supermarket, dan 66 mini market di wilayah Kecamatan Kebayoran Baru (BPS, 2017). Menariknya, sebagian jumlah ini berbeda cukup signifikan dengan data sensus kecamatan pada 2010 silam. Lebih lengkapnya, pada tabel di bawah ini bisa dilihat jumlah pasar dan pusat perbelanjaan di wilayah Kecamatan Kebayoran Baru dan perbandingannya antara tahun 2010 dan 2014.

Tabel 1. Daftar Pusat Perbelanjaan di Kawasan Jakarta Selatan

\begin{tabular}{|l|c|c|}
\hline Jenis Pusat Perbelanjaan & $\mathbf{2 0 1 0}$ & $\mathbf{2 0 1 4}$ \\
\hline Pasar Inpres & 6 & 1 \\
\hline Pasar Tradisional & 4 & 5 \\
\hline Pasar Swalayan & 32 & 6 \\
\hline Mall & 8 & 6 \\
\hline Waserda & 18 & 2 \\
\hline Mini Market Jumlah Total & 18 & 66 \\
\hline \multicolumn{2}{|c|}{} & $\mathbf{8 6}$ \\
\hline
\end{tabular}

Sumber: BPS Kota Adm. Jakarta Selatan 2015

Dari tabel di atas bisa dilihat bahwa terdapat perbedaan yang cukup signifikan pada kategori mini market. Selama empat tahun terjadi peningkatan jumlah yakni dari 18 menjadi 66 mini market. Pertumbuhan mini-market tidak diiringi dengan pertumbuhan pusat perbelanjaan lainnya, seperti jumlah waserda, pasar inpres, dan juga pasar swalayan yang terus berkurang. Menariknya, berkurangnya pasar swalayan secara drastis selama empat tahun tersebut memberikan indikasi bahwa perkembangan plaza, mall, dan pusat perbelanjaan bisa saja memiliki pengaruh atas fenomena ini. Hal ini juga bisa memberi gambaran kepada pembaca bahwa situasi bisnis di kawasan Kebayoran Baru cukup kompetitif.

Selain dari jumlah pasar dan pusat perbelanjaan, aktivitas perekonomian masyarakat juga bisa dilihat dari ju mlah industri yang berada di kawasan tersebut. Dari data BPS Provinsi DKI Jakarta, jumlah industri kecil (5-19 pekerja) dan industri rumahan (1-4 pekerja) di kawasan Kebayoran Baru mengalami peningkatan pada rentang tahun 2012 hingga 2014. Pada tabel di bawah ini digambarkan peningkatan jumlah industri kecil di kawasan Kebayoran Baru. 
INOBIS: Jurnal Inovasi Bisnis dan Manajemen Indonesia

Vol. 02, No. 03, Bulan Juni 2020

Noveri Maulana, Joshua Michael Hutagalung

Tabel 2. Daftar Industri di Kebayoran Baru

\begin{tabular}{|l|c|c|}
\hline \multicolumn{1}{|c|}{ Jenis Industri } & $\mathbf{2 0 1 2}$ & $\mathbf{2 0 1 4}$ \\
\hline Industri Kecil & 14 & 20 \\
\hline Industri Rumah Tangga & 57 & 64 \\
\hline Jumlah Total & $\mathbf{7 1}$ & $\mathbf{8 4}$ \\
\hline
\end{tabular}

Sumber: BPS Kota Adm. Jakarta Selatan

Selain industri kecil dan rumahan dari berbagai bidang, di kawasan Kebayoran Baru juga banyak terdapat usaha masyarakat lainnya seperti salon kecantikan, bengkel mobil dan motor, penjualan mobil dan motor, serta penjahit dan usaha masyarakat lainnya. Oleh Karena itu, aktivitas perekonomian masyarakat yang didukung dengan keberadaan kawasan permukiman dan pusat perbelanjaan juga menarik kehadiran berbagai bank nasional dan daerah untuk membuka kantor cabang di kawasan ini.

Dari kondisi tersebut, kehadiran pusat perbelanjaan modern di Kawasan Blok M, Kebayoran Baru, Jakarta, menjadi sebuah tantangan bagi kondisi ekonomi dan sosial di sekitar Kawasan pusat perbelanjaan tersebut. Dampak pembangunan pusat perbelanjaan modern sejatinya juga harus diikuti dengan kajian yang komprehensif mengenai dampak sosial dan ekonomi untuk lingkungan sekitar. Penelitian ini memberikan alternatif strategi bagi manajemen pusat perbelanjaan dalam Menyusun kerangka strategi pengelolaan dampak sosial dan ekonomi tersebut.

\section{Landasan Teori}

Menggunakan analisis SWOT dan TOWS Matriks, penulis akan menyusun pilihan strategi bagi perusahaan untuk mengelola dampak sosial dan ekonomi tersebut sehingga bisa memberikan solusi terbaik bagi seluruh pihak, terutama masyarakat di sekitar kawasan Kebayoran Baru. Analisis SWOT adalah identifikasi berbagai faktor secara sistematis untuk merumuskan strategi perusahaan dalam menghadapi sebuah persoalan (Fred, 2015). Dalam hal ini dalam merumuskan strategi penanggulangan dampak sosial ekonomi kemasyarakatan. Analisis ini didasarkan pada logika yang dapat memaksimalkan kekuatan (Strenghts) dan peluang (Oppurtunities), namun secara bersamaan dapat meminimalkan kelemahan (Weaknesess) dan ancaman (Threats) (Putra \& Maulana, 2018; Weihrich, 1982). Sedangkan, TOWS Matriks merupakan proses penggalian alternatif strategi dari komponen SWOT yang sudah diperoleh pada analisis sebelumnya. TOWS matriks adalah sebuah alat yang dapat digunakan untuk menciptakan faktor strategis perusahaan. Bagaimana peluang dan ancaman dihadapi oleh perusahaan dapat disesuaikan dengan kekuatan dan kelemahan yang dimiliki oleh perusahaan tersebut. TOWS matrix akan memberikan empat set dari strategi alternatif bagi perusahaan (Ravanavar, 2012).

Pertama, ialah Strategi SO (Strength-Opportunities). Strategi ini diformulasikan berdasarkan faktor internal perusahaan, yang didesain dengan menggunakan kekuatan perusahaan untuk memperoleh kesempatan yang tercipta dari keadaan lingkungan (peluang eksternal). Kedua ialah Strategi WO (Weakness-Opportunities). Strategi ini diformulasikan dengan menggunakan kesempatan yang disediakan oleh lingkungan agar kelemahan perusahaan dapat diminimalisir sekecil mungkin dengan memanfaatkan peluang eksternal yang tersedia. 
Ketiga ialah Strategi ST (Strength-Threat). Strategi ini diformulasikan dengan menggunakan kekuatan perusahaan untuk mengatasi ancaman yang datang dari lingkungan sekitar. Terakhir, ialah Strategi WT (Weakness-Threat). Strategi ini diformulasikan untuk menghadapi dan mengurangi dampak dari ancaman eksternal serta untuk meminimalisir risiko yang bisa melanda perusahaan (Ravanavar, 2012).

Tabel 3. Tabel TOWS Matriks

\begin{tabular}{|c|c|c|}
\hline & $\begin{array}{c}\text { STRENGTHS } \\
(\boldsymbol{S})\end{array}$ & WEAKNESS $(\boldsymbol{W})$ \\
\hline OPPORTUNITIES $(\boldsymbol{O})$ & Strategi S-O & Strategi W-O \\
\hline THREATS $(\boldsymbol{T})$ & Strategi S-T & Strategi W-T \\
\hline
\end{tabular}

\section{Metode Penelitian}

Penelitian ini menggunakan pendekatan kualitatif karena ditujukan untuk melakukan elaborasi fenomena (Sekaran \& Bougie, 2011). Penelitian kualitatif memberikan kesempatan kepada peneliti untuk memberikan interpretasi subjektif mereka berdasarkan data yang diperoleh di lapangan. Lebih lanjut, penelitian kualitatif mengutamakan penekatan induktif yang tidak melakukan uji hipotesis pada model penelitiannya. Oleh karena itu, hasil penelitian kualitatif akan memaparkan narasi interpretatif yang dilakukan peneliti (Wahyuni, 2019). Penelitian kualitatif ini menggunakan pendekatan fenomenologi, yaitu studi realitas sosial yang didasarkan pada fenomena yang terjadi di tengah masyarakat. Peneliti berargumen bahwa dampak sosial dan ekonomi pembangunan pusat perbelanjaan merupakan sebuah fenomena sosial yang harus dikaji dengan berbagai sudut pandang. Oleh karena itu, pendekatan fenomenologi memberi ruang bagi peneliti untuk melakukan kajian mendalam terhadap fenomena tersebut (Wahyuni, 2019).

Metode pengumpulan data dilakukan dengan beberapa pendekatan, yaitu studi dokumen, wawancara, survey dengan kuesioner, dan observasi lapangan. Keempat jenis data tersebut untuk memastikan validitas dan reliabilitas data yang dikumpulkan. Sehingga, dengan memiliki empat jenis data, triangulasi data bisa dilakukan dengan baik (Huberman \& Miles, 2012). Studi dokumen dilakukan dengan mengumpulkan data-data terkait jumlah pusat perbelanjaan di kawasan Jakarta Selatan, demografi penduduk, profil wilayah Jakarta Selatan, dan juga kajian terhadap penelitian terdahulu. Data-data tersebut diperoleh dari Badan Pusat Statistik (BPS), data publik yang ditampilkan pada laman Pemerintah Provinsi DKI Jakarta, serta data dari arsip yang diakses di Kantor Walikota Jakarta Selatan. Data dokumen tersebut kemudian diolah dengan pendekatan content analysis.

Sedangkan wawancara mendalam dilakukan dengan manajamen pusat perbelanjaan di kawasan Blok M, tokoh masyarakat pada permukiman di sekitar kawasan Blok M, dan juga wawancara pada pengamat sosial budaya di beberapa komunitas dan perguruan tinggi. Data dari wawancara tersebut diolah dengan pendekatan narrative analysis (Stritch et al., 2017). Ketiga ialah data yang diperoleh dari survey pelanggan. Kami melakukan survey kepada 176 pelanggan yang mengunjungi pusat perbelanjaan modern di kawasan Blok M. Survey dilakukan untuk memperoleh data deskriptif mengenai opini pengunjung terhadap kualitas pusat perbelanjaan dan menggali pendapat mereka terhadap aspek sosial dan ekonomi pusat perbelanjaan terhadap masyarakat sekitar. Data hasil survey tersebut diolah dengan 
menggunakan statistik deskriptif untuk kemudian diinterpretasi oleh peneliti ke dalam kategorisasi temuan hasil studi (Maxwell \& Reybold, 2015).

Terakhir ialah melakukan observasi lapangan ke beberapa pusat perbelanjaan yang ada di kawasan Blok $\mathrm{M}$ dan juga perkampungan masyarakat yang ada di sekitar kawasan Blok $\mathrm{M}$. Penulis melakukan observasi dengan mengamati kondisi perekonomian masyarakat dan juga mengamati bukti fisik (tangible) dari hubungan kerjasama antara pengelola pusat perbelanjaan dengan komunitas masyarakat sekitar, seperti penyediaan sarana dan prasarana umum untuk masyarakat.Seluruh data yang sudah dikumpulkan kemudian diberikan kode dan dikelompokkan pada kategorisasi tertentu. Dalam penelitian ini, penulis menggunakan empat jenis kategori data yang dianalisis berdasarkan framework SWOT. Seluruh data yang diperoleh kemudian penulis kelompokkan berdasarkan kategori strength, weakness, opportunity, dan threat. Kemudian, data yang sudah dikelompokkan tersebut selanjutnya dianalisis ke dalam TOWS Matriks untuk mencari alternatif solusi yang bisa disimpulkan dari hasil studi ini (Ravanavar, 2012).

\section{Pembahasan}

Seluruh data yang disajikan dalam tabel hasil analisis SWOT dibagi ke dalam dua kategori, yaitu data primer yang berasal dari wawancara dengan tokoh masyarakat dan juga manajemen Plaza Blok M, serta kedua ialah data sekunder dengan menganalisis data kualitas pelayanan dan survey konsumen, serta data kependudukan yang diperoleh dari Badan Pusat Statistik Jakarta Selatan. Seluruh data diolah kembali untuk menguji validitas dan realibitasnya dengan metode triangulasi. Data disandingkan dengan dua sumber lainnya dan menghasilkan sebuah simpulan analisis yang valid dan teruji sesuai dengan data dan fakta yang penulis temukan di lapangan. Selain itu, proses triangulasi juga dilakukan dengan melakukan perbandingan antara data primer dan sekunder yang telah penulis analisis. Tabel berikut ini menggambarkan seluruh kategori data yang sudah diperoleh oleh peneliti.

Tabel 4. Coding dan Kategorisasi Data Penelitian

\begin{tabular}{|l|l|l|}
\hline Kategorisasi & $\begin{array}{c}\text { Sumber } \\
\text { Data }\end{array}$ & \multicolumn{1}{c|}{ Interpretasi Data } \\
\hline & & $\begin{array}{l}\text { Menurut data yang didapat dari Survey pelanggan } \\
\text { didapatkan opini dari pengunjung bahwa mayoritas tenant- } \\
\text { tenant yang dimiliki pusat perbelanjaan modern Blok M } \\
\text { menawarkan produk dan jasa yang terjangkau oleh } \\
\text { kelompok masyarakat sekitar. } \\
\text { Survey } \\
\text { Pelanggan \& } \\
\text { Observasi } \\
\text { Lapangan } \\
\text { Pusat Perbelanjaan modern di kawasan Blok M memiliki } \\
\text { akses yang terintegrasi, sehingga memudahkan masyarakat } \\
\text { dalam beraktivitas dan berinteraksi. } \\
\text { Keberadaan pusat perbelanjaan di kawasan Blok M } \\
\text { memberi dampak positif kepada masyarakat karena } \\
\text { dianggap memberi kemudahan dalam akses kebutuhan } \\
\text { primer dan sekunder masyarakat sekitar. } \\
\text { Selain itu, pusat perbelanjaan modern di kawasan Blok M } \\
\text { juga membuka peluang kerja baru bagi masyarakat yang } \\
\text { tinggal di sekitar kawasan tersebut. }\end{array}$ \\
\hline
\end{tabular}




\begin{tabular}{|c|c|c|}
\hline $\begin{array}{c}\text { Strength } \\
(S)\end{array}$ & $\begin{array}{l}\text { Interview } \\
\text { Manajemen }\end{array}$ & $\begin{array}{l}\text { Bekerjasama dengan banyak komunitas dan organisasi } \\
\text { dalam mengadakan kegiatan kemasyarakat dan program } \\
\text { korporat. } \\
\text { Beberapa pusat perbelanjaan sudah menerapkan Standar } \\
\text { ISO 9001: 2008 untuk pelayanan dan pengelolaan } \\
\text { manajemen yang baik } \\
\text { Tersedianya dengan baik Fasilitas Sosial dan Umum } \\
\text { (FASOS dan FASUM) dengan baik terlihat dari beberapa } \\
\text { bangunan fisik sekitar komplek pusat perbelanjaan Blok M } \\
\text { seperti; Taman, tempat penjemputan Ojek Online, Tempat } \\
\text { beribadah di dalam mall dan Atrium plaza yang menjadi } \\
\text { tempat acara sosial. }\end{array}$ \\
\hline & $\begin{array}{l}\text { Survey } \\
\text { Pelanggan } \\
\text { dan Data BPS } \\
\text { DKI }\end{array}$ & $\begin{array}{l}\text { Menurut data survey terdapat beberapa opini dari } \\
\text { pengunjung yang merasakan pengalaman dengan binatang } \\
\text { hama (tikus, kecoa) di sekitar kawasan pusat perbelanjaan. } \\
\text { Isu kebersihan menjadi tantangan baru atas keberadaan } \\
\text { pusat perbelanjaan tersebut. } \\
\text { Beberapa bangunan yang sudah tua di kawasan tersebut } \\
\text { membuat khawatir pengunjung dan masyarakat sekitar. } \\
50 \% \text { pengunjung pusat perbelanjaan modern berasal dari } \\
\text { kalangan menengah dengan pendapatan sebesar Rp. } 5 \text { juta } \\
\text { per bulan, padahal plaza ditujukan pada komunitas } \\
\text { menengah ke atas. Hal ini menjadi tantangan bagi } \\
\text { manajemen. }\end{array}$ \\
\hline $\begin{array}{c}\text { Weakness } \\
\text { (W) }\end{array}$ & $\begin{array}{l}\text { Interview } \\
\text { Masyarakat } \\
\text { dan } \\
\text { Manajemen }\end{array}$ & $\begin{array}{l}\text { Masyarakat merasa program CSR (Corpotate Sosial } \\
\text { Responsibility) yang dilakukan oleh pihak manajemen } \\
\text { pusat perbelanjaan modern belum optimal. } \\
\text { Optimalisasi tenaga kerja masih belum dirasa maksimal } \\
\text { oleh masyarakat sekitar, walau manajemen telah } \\
\text { menerapkan perekrutan bagi warga KTP Jakarta Selatan. }\end{array}$ \\
\hline & $\begin{array}{l}\text { Survey } \\
\text { Pelanggan, } \\
\text { Observasi, } \\
\text { dan Data } \\
\text { BPS DKI }\end{array}$ & $\begin{array}{l}\text { Proyek MRT akan bekerja sama dengan beberapa Pusat } \\
\text { Perbelanjaan di Blok M untuk membangun stasiun. } \\
\text { Dengan kegiatan rutin keamanan yang dilakukan } \\
\text { kepolisian setempat, wilayah Kel. Kramat Pela mampu } \\
\text { meningkatkan keamanan di kawasan sekitar Pusat } \\
\text { perbelanjaan. } \\
\text { Masyarakat sekitar Mall mendapatkan manfaat ekonomi } \\
\text { atas keberadaan Plaza Blok M, seperti potensi bisnis } \\
\text { makanan, kos-kosan, parkir, dan lainnya. }\end{array}$ \\
\hline $\begin{array}{c}\text { Opportunity } \\
(\mathrm{O})\end{array}$ & $\begin{array}{l}\text { Interview } \\
\text { Masyarakat } \\
\text { dan } \\
\text { Manajemen }\end{array}$ & $\begin{array}{l}\text { Kegiatan pusat perbelanjaan yang ramai dan terkontrol } \\
\text { dengan baik mampu mengurangi aktivitas penyakit } \\
\text { masyarakat yang berada di sekitar wilayah pusat } \\
\text { perbelanjaan. } \\
\text { Kawasan Kebayoran Baru yang sudah tertata dengan baik } \\
\text { memberi peluang kehadiran Pusat Perbelanjaan modern } \\
\text { sebagai bagian kehidupan masyarakat }\end{array}$ \\
\hline
\end{tabular}


INOBIS: Jurnal Inovasi Bisnis dan Manajemen Indonesia

Vol. 02, No. 03, Bulan Juni 2020

Noveri Maulana, Joshua Michael Hutagalung

\begin{tabular}{|c|l|l|}
\hline & & $\begin{array}{l}\text { Pembinaan masyarakat melalui upaya pelatihan wirausaha } \\
\text { dan KUKM sebagai bagian upaya pengentasan kemiskinan. }\end{array}$ \\
\hline \multirow{5}{*}{ Threat } & $\begin{array}{l}\text { Survey } \\
\text { Pelanggan } \\
\text { dan Data } \\
\text { BPS DKI }\end{array}$ & $\begin{array}{l}\text { Perubahan budaya masyarakat yang lebih konsumtif dan } \\
\text { shock budaya. } \\
\text { Angka kemiskinan yang meningkat di wilayah Kebayoran } \\
\text { Baru membuat kondisi masyarakat yang tidak stabil dan } \\
\text { merata. }\end{array}$ \\
\cline { 2 - 4 } & $\begin{array}{l}\text { Interview } \\
\text { Masyarakat } \\
\text { dan } \\
\text { Manajemen }\end{array}$ & $\begin{array}{l}\text { Minimnya penyerapan Tenaga Kerja kepada warga sekitar } \\
\text { Kel. Kramat Pela yang telah dilakukan oleh beberapa } \\
\text { manajemen pusat perbelanjaan modern. } \\
\text { Tuntutan dari masyarakat dan kelompok masyarakat yang } \\
\text { merasa dirugikan / kalah dari kompetisi bisnis di sekitar } \\
\text { kawasan pusat perbelanjaan modern. }\end{array}$ \\
\hline
\end{tabular}

Sumber: Hasil olahan peneliti 
Dari tabel di atas bisa dilihat bahwa komponen strength, weakness, opportunity, dan threat yang didapat dari beberapa teknik pengumpulan data terlah memberikan gambaran analisis yang bisa dilakukan oleh peneliti. Namun, interpretasi peneliti dalam studi ini tidak hanya dilakukan secara subjektif semata, namun juga dengan perspektif yang objektif berdasarkan triangulasi data yang telah dilakukan. Seluruh data yang diperoleh dan dikelompokkan pada tabel SWOT tersebut, kemudian dianalisi dengan menggunakan TOWS Matriks. Analisis ini untuk melihat berbagai alternatif strategi dengan menggabungkan komponen eksternal (Opportunity \& Threat), dengan komponen internal (Strength \& Weakness) sehingga bisa melahirkan berbagai alternatif strategi sesuai dengan topik penelitian (Weihrich, 1982). Dalam hal ini, TOWS matriks akan memberikan alternatif penanganan dampak sosial dan ekonomi terhadap masyarakat sekitar atas pengembangan pusat perbelanjaan modern di kawasan Blok $\mathrm{M}$.

Dalam TOWS Matriks, strategi yang diformulasikan akan dikelompokkan ke dalam beberapa pilihan strategy, yaitu ST Strategy, WT Strategy, SO Strategy, dan WO Strategy. Keempat kelompok strategy tersebut akan memberi pilihan bagi pemangku kepentingan untuk melihat faktor peluang, ancaman, kekuatan, dan kelemahan yang bisa diformulasikan ke dalam sebuah pendekatan integratif yang bisa bermanfaat dalam pengelolaan dampak sosial dan ekonomi pembangunan pusat perbelanjaan modern.

Dalam menyusun formulasi strategi dalam TOWS Matriks, proses formulasi komponen SWOT tersebut bisa dilakukan dalam beberapa bentuk kolaborasi, yaitu satu komponen faktor eksternal diformulasikan dengan satu komponen faktor internal. Bahkan lebih lanjut, multifaktor dari masing-masing kelompok data tersebut bisa diformulasikan secara bersamaan. Misalnya, satu komponen strength bisa diformulasikan dengan satu, dua, atau lebih dari komponen opportunity sehingga bisa menghasilkan satu strategy SO. Begitu pula dalam membangun strategy WO, satu, dua, atau lebih komponen weakness bisa diformulasikan dengan satu atau lebih komponen opportunity. Sehingga, dalam TOWS Matriks, peneliti bisa melakukan analisis secara lebih komprehensif dengan memformulasikan banyak komponen secara single component maupun secara multi-component secara bersamaan. Semakin banyak proses formulasi yang dilakukan di dalam TOWS Matriks, maka akan semakin banyak pula alternatif strategi yang bisa dihasilkan. Untuk lebih jelasnya, bisa dilihat pada tabel 5 berikut ini.

Tabel 5. Hasil Analisis Menggunakan TOWS Matriks

\begin{tabular}{|l|l|l|}
\hline \multirow{4}{*}{ TOWS Matriks } & \multicolumn{1}{|c|}{ Strengths (S) } & \multicolumn{1}{c|}{ Weaknesses (W) } \\
\cline { 2 - 3 } & $\begin{array}{l}\text { (S1) Harga produk } \\
\text { terjangkau \& sesuai } \\
\text { segmentasi }\end{array}$ & $\begin{array}{l}\text { (W1) Bangunan cukup } \\
\text { tua dan lama }\end{array}$ \\
\cline { 2 - 3 } $\begin{array}{l}\text { (S2) Terdapat fasilitas } \\
\text { umum dan sosial } \\
\text { (bioskop, masjid, dll) }\end{array}$ & $\begin{array}{l}\text { (W2) Hama tikus, kecoa, } \\
\text { Amdal yang belum } \\
\text { optimal }\end{array}$ \\
\cline { 2 - 3 } & (S3) Lokasi strategis & $\begin{array}{l}\text { (W3) Pengunjung } \\
\text { didominasi segmen } \\
\text { menengah }\end{array}$ \\
\cline { 2 - 3 } & $\begin{array}{l}\text { (S4) Kegiatan CSR } \\
\text { optimal di wilayah sekitar }\end{array}$ \\
\hline
\end{tabular}




\begin{tabular}{|c|c|c|c|}
\hline & $\begin{array}{l}\text { (S5) Kekuatan jaringan } \\
\text { Pakuwon Group }\end{array}$ & $\begin{array}{l}\text { (W5) optimalisasi } \\
\text { perekrutan tenaga kerja } \\
\text { sekitar }\end{array}$ \\
\hline & & $\begin{array}{l}\text { (S6) standar ISO } \\
9001: 2008\end{array}$ & \\
\hline \multirow{6}{*}{$\begin{array}{l}\text { Oppor } \\
\text { tunity }\end{array}$} & $\begin{array}{l}\text { (O1) Integrasi halte } \\
\text { MRT dan Plaza Blok } \\
\text { M }\end{array}$ & \multirow{2}{*}{$\begin{array}{c}\text { (SO-1) Membuka ruang } \\
\text { publik yang lebih } \\
\text { menarik, ramah anak, } \\
\text { lansia, dan disabilitas, } \\
\text { serta mampu memenuhi } \\
\text { kebutuhan interaksi } \\
\text { masyarakat }(S 1, S 2, S 3, \\
S 6, O 1, O 2, O 4) \\
\end{array}$} & \multirow{3}{*}{$\begin{array}{c}\text { (WO-1) Sosialisasi } \\
\text { pemeliharaan gedung } \\
\text { untuk memberikan rasa } \\
\text { aman bagi warga dan } \\
\text { konsumen }(W 1, W 2, O 4 \text {, } \\
O 5)\end{array}$} \\
\hline & $\begin{array}{l}\text { (O2) Kegiatan } \\
\text { keamanan yang baik } \\
\text { dan terkoneksi dengan } \\
\text { Kepolisian }\end{array}$ & & \\
\hline & $\begin{array}{l}\text { (O3) Manfaat ekonomi } \\
\text { bagi pedagang, kos2an, } \\
\text { dan parkir }\end{array}$ & \multirow{2}{*}{$\begin{array}{c}\text { (SO-2) Pembinaan } \\
\text { komunitas warga sekitar } \\
\text { Plaza untuk pengelolaan } \\
\text { usaha Makanan, rumah } \\
\text { kos, dan lahan parkir } \\
\text { warga }(S 4, S 5, O 3, O 5, \\
O 6)\end{array}$} & \\
\hline & $\begin{array}{l}\text { (O4) Sistem yang } \\
\text { terkontrol sehingga } \\
\text { berdampak baik bagi } \\
\text { masyarakat }\end{array}$ & & \multirow{3}{*}{$\begin{array}{c}\text { (WO-2) Optimalisasi } \\
\text { kegiatan CSR di wilayah } \\
\text { sekitar Plaza secara } \\
\text { berkelanjutan }(W 4, W 5 \text {, } \\
\text { O3, O5, O6) }\end{array}$} \\
\hline & $\begin{array}{l}\text { (O5) Pusat } \\
\text { Perbelanjaan sebagai } \\
\text { bagian kehidupan } \\
\text { masyarakat }\end{array}$ & \multirow{2}{*}{$\begin{array}{l}\text { (SO-3) Bekerjasama } \\
\text { dengan aparatur } \\
\text { keluarahan untuk } \\
\text { memanfaatkan fasilitas } \\
\text { Plaza bagi kegiatan } \\
\text { kemasyarakatan }(S 4, S 5 \text {, } \\
\text { O5, O6) }\end{array}$} & \\
\hline & $\begin{array}{l}\text { (O6) Potensi } \\
\text { pembinaan KUKM }\end{array}$ & & \\
\hline \multirow{5}{*}{$\begin{array}{c}\text { Threat } \\
\text { (T) }\end{array}$} & $\begin{array}{l}\text { (T1) Potensi Banjir di } \\
\text { kawasan }\end{array}$ & \multirow{3}{*}{$\begin{array}{l}\text { (ST-1) Upaya pengelolaan } \\
\text { lingkungan yang baik } \\
\text { bekerjasama dengan } \\
\text { masyarakt sekitar }(S 4, S 5 \text {, } \\
\text { S6, T1,T2,T3,T5) }\end{array}$} & \multirow{3}{*}{$\begin{array}{l}\text { (WT-1) Membangun } \\
\text { hubungan baik secara } \\
\text { rutin dan berkala dengan } \\
\text { masyarakat dan aparatur } \\
\text { pemerintahan }(W 1, W 2, \\
W 3, W 4, W 5, T 2, T 3, T 5)\end{array}$} \\
\hline & $\begin{array}{l}\text { (T2) Perubahan budaya } \\
\text { masyarakat yang } \\
\text { konsumtif }\end{array}$ & & \\
\hline & $\begin{array}{l}\text { (T3) Angka } \\
\text { kemiskinan yang } \\
\text { meningkat } \\
\end{array}$ & & \\
\hline & $\begin{array}{l}\text { (T4) Penyerapan } \\
\text { Tenaga kerja dari } \\
\text { lingkungan sekitar } \\
\text { yang minim }\end{array}$ & \multirow{2}{*}{$\begin{array}{l}\text { (ST-2) Optimalisasi } \\
\text { kerjasama dan perekrutan } \\
\text { tenaga kerja dari warga } \\
\text { sekitar }(S 4, S 5, T 4, T 5)\end{array}$} & \multirow{2}{*}{$\begin{array}{c}\text { (WT-2) Integrasi } \\
\text { pengelolaan lingkungan, } \\
\text { CSR, dan program } \\
\text { kemasyarakatan yang } \\
\text { terintegrasi di bawah } \\
\text { koordinasi Grup } \\
\text { Perusahaan }(W 1, W 2, W 4, \\
W 5, T 1, T 2, T 3)\end{array}$} \\
\hline & $\begin{array}{l}\text { (T5) Persaingan usaha } \\
\text { dengan warga } \\
\text { dikhawatirkan } \\
\text { menimbulkan gesekan }\end{array}$ & & \\
\hline
\end{tabular}

Sumber: Hasil olahan peneliti 
Dari hasil analisis TOWS Matriks tersebut, maka dapat ditarik sembilan alternatif strategi penanganan dampak sosial dan ekonomi pembangunan pusat perbelanjaan modern di kawasan Blok M terhadap masyarakat sekitar. Alternatif strategi ini bisa menjadi rujukan bagi manajemen pusat perbelanjaan dan juga pemangku kepentingan agar mampu meningkatkan koordinasi dan kerjasama dalam berbagai hal demi terciptanya ketentraman dan kenyamanan masyarakat. Kesembilan alternatif strategi tersebut dijelaskan pada paragraf berikut ini. Pertama ialah strategi SO-1 yaitu membuka ruang publik yang lebih menarik, ramah anak, lansia, dan disabilitas, serta mampu memenuhi kebutuhan interaksi masyarakat. Strategi ini berupaya untuk memberi peluang kepada publik untuk merasa lebih aman dan nyaman untuk berinteraksi dengan memanfaatkan fasilitas yang ada di pusat perbelanjaan. Hal ini juga akan mampu berdampak besar bagi peran perusahaan dalam menciptakan hubungan baik antara perusahaan dan masyarakat sekitar.

Kedua ialah strategi SO-2 yaitu pembinaan komunitas warga sekitar pusat perbelanjaan modern untuk pengelolaan usaha makanan, rumah kos, dan lahan parkir milik warga. Tidak bisa dipungkiri bahwa keberadaan pusat perbelanjaan juga memberikan dampak ekonomi yang positif bagi masyarakat sekitar (Munawar, 2009). Meningkatnya kebutuhan akan tempat tinggal dan makanan adalah beberapa contohnya. Hal ini tentu membuka peluang pekerjaan baru bagi warga sekitar untuk membuka bisnis rumah kos dan juga usaha makanan. Hal ini sejatinya bisa menjadi salah satu alternative bagi perusahaan untuk melakukan pembinaan sehingga dampak negatif keberadaan pusat perbelanjaan bisa diminimalisirkan.

Ketiga ialah strategi SO-3, yaitu bekerjasama dengan aparatur pemerintahan setempat untuk memanfaatkan fasilitas pusat perbelanjaan modern bagi kegiatan kemasyarakatan, seperti seminar untuk publik, kegiatan sosial dan keagamaan, serta lainnya. Hal ini tentu akan bisa menimbulkan citra positif bagi perusahaan dan juga meningkatkan hubungan baik antara manajemen dan masyarakat sekitar (Stäbler \& Fischer, 2020). Keempat ialah strategi WO-1 yaitu sosialisasi pemeliharaan gedung untuk memberi rasa aman dan nyaman bagi masyarakat. Kehadiran pusat perbelanjaan di kawasan Blok M sejak dua dekade silam memberi penilaian yang cukup miring terhadap usia bangunan dan juga faktor keselamatan dan keamanannya. Transparansi pengelolaan dan audit bangunan bisa menjadi salah satu upaya peningkatan citra kemanan bagi masyarakat. Sosialisasi hendaknya tidak terbatas pada pengelolaan bangunan saja, tapi juga terkait pengelolaan limbah seperti penanganan sampah dan hama tikus serta serangga lainnya.

Kelima ialah strategi WO-2 yaitu optimalisasi kegiatan CSR di wilayah sekitar pusat perbelanjaan secara berkelanjutan. Salah satu isu yang paling banyak penulis temukan dalam penelitian ini ialah terkait pelaksanaan program CSR yang masih belum optimal dan merata yang dirasakan oleh masyarakat sekitar kawasan. Padahal, dari data yang diperoleh dari pihak perusahaan, jumlah kegiatan CSR dari beberapa pusat perbelanjaan di kawasan Blok M sudah banyak dilakukan. Namun, penulis melihat bahwa keberlanjutan program dan ketepatan sasaran kegiatannya masih perlu dikaji lebih lanjut.

Keenam ialah strategi ST-1 yaitu upaya pengelolaan lingkungan yang baik bekerjasama dengan pemerintah di sekitar kawasan. Hal ini senada dengan usulan strategi WO-2 di atas yang merekomendasikan pihak perusahaan agar mengoptimalkan kegiatan dan hubungan baik dengan aparatur pemerintahan setempat dan juga tokoh masyarakat sekitar pusat perbelanjaan.. Ketujuh ialah strategi ST-2 yaitu optimalisasi kerjasama dalam perekrutan tenaga kerja sekitar lingkungan pusat perbelanjaan. Hal ini menjadi salah satu isu sosial yang seringkali memicu gesekan antara manajemen dan warga sekitar. Pihak perusahaan diharapkan mampu menangani hal ini dengan memberikan pemahaman, pelatihan, dan pembinaan terhadap masyarakat sekitar 
sehingga mereka merasa mendapatkan perlakuan yang sama dengan para pelamar kerja lainnya.

Kedelapan ialah strategi WT-1 yaitu membangun hubungan baik secara rutin dan berkala dengan aparat pemerintahan dan masyarakat sekitar. Hal ini bisa dilakukan dengan menyediakan fasilitas Pusat perbelanjaan untuk kegiatan kemasyarakatan ataupun dengan mengundang kehadiran tokoh masyarakat dan aparat pemerintahan dalam program-program tertentu yang diselenggarakan di dalam lingkungan Pusat perbelanjaan. Tentu, hubungan baik yang dijalin secara rutin dan berkelanjutan ini akan memberikan dampak positif bagi kedua belah pihak (Wibowo et al, 2019).

Terakhir ialah strategi WT-2 yaitu Integrasi pengelolaan lingkungan, CSR, dan program kemasyarakatan di bawah satu payung kawasan Blok M. Kehadiran asosiasi pengelola pusat perbelanjaan di kawasan Blok $M$ akan memberi dampak yang sangat baik bagi pengelolaan hubungan dengan stakeholder, termasuk masyarakat lingkungan sekitar. Peran asosiasi atau forum komunikasi pengelola kawasan ini mampu memberi program yang terintegrasi antara satu pusat perbelanjaan dengan yang lainnya. Hal ini tentu akan memudahkan dalam pengelolaan dampak sosial dan ekonomi terhadap masyarakat sekitar, terutama hal yang terkait pengelolaan lingkungan, CSR, dan aktivitas kemasyarakatan lainnya.

\section{Kesimpulan}

Dari analisis yang telah dilakukan, manajemen pusat perbelanjaan modern di kawasan Blok M memiliki beberapa alternatif strategi dalam mengelola dampak sosial dan ekonomi atas pembangunan pusat perbelajaan modern di kawasan Blok M, Jakarta Selatan. Alternatif strategi tersebut didapatkan dari analisis TOWS Matriks yang bersumber pada data primer dan sekunder yang telah diolah oleh peneliti. Dari sembilan strategi yang dihasilkan, penulis menyarankan agar manajemen pusat perbelanjaan bisa melakukan empat strategi pilihan utama dalam sesuai dengan prioritas strategi dan sumber daya yang dimiliki. Keempat strategi tersebut penulis jelaskan pada paragraf berikut ini.

Pertama ialah optimalisasi hubungan dengan tokoh masyarakat dan aparat pemerintahan. Kedua belah pihak diharapkan mampu aktif untuk saling berkoordinasi. Semakin baik koordinasi maka akan semakin mudah pula penanganan dampak sosial kemasyarakatan tersebut. Kedua ialah penanganan ruang publik dan fasilitas umum diharapkan lebih mendapat perhatian serius dari manajemen pusat perbelanjaan. Hal ini tidak hanya sebagai bentuk kepedulian masyarakat, tetapi juga akan berdampak pada peningkatan pengunjung nantinya (Dębek, 2015).

Ketiga ialah pembinaan masyarakat terkait kewirausahaan, UMKM, dan aktivitas di pasar tradisional juga perlu melibatkan manajemen salah satunya melalui kegiatan CSR secara berkala. Pemberdayaan masyarakat akan mampu memberi pengaruh terhadap penanganan dampak sosial dan ekonomi yang negatif, sehingga bisa ditransformasi menjadi dampak positif melalui kegiatan CSR perusahaan (Heffner \& Twardzik, 2015). Keempat ialah terkait sosialisasi dan komunikasi aktif terhadap masyarakat juga perlu ditingkatkan, tidak hanya untuk aktivitas promosi tetapi juga mencakup kegiatan edukasi. Selain itu, komunikasi terkait optimalisasi penyerapan tenaga kerja juga perlu disampaikan agar tidak menimbulkan masalah horizontal di kemudian hari.

Diharapkan penelitian ini bisa memberikan kontribusi positif terhadap perancangan pengelolaan dampak sosial dan ekonomi pembangunan pusat perbelanjaan modern di kota-kota besar. Walau penelitian ini mengambil unit analisis di Jakarta, namun metode penelitian bisa diterapkan pada unit analisis lainnya yang relevan. Oleh karena itu, penelitian selanjutnya juga 
INOBIS: Jurnal Inovasi Bisnis dan Manajemen Indonesia

Vol. 02, No. 03, Bulan Juni 2020

Noveri Maulana, Joshua Michael Hutagalung

bisa dikembangkan oleh para peneliti dan praktisi dengan menerapkan analisis TOWS Matriks secara komprehensif.

\section{Daftar Pustaka}

Aisyah, S. (2015). PENGARUH PEMBANGUNAN GRAND MALL TERHADAP PENDAPATAN UMKM DI KOTA PALU. ISTIQRA Jurnal Penelitian Ilmiah, 3(1), $32-50$.

BPS, J. (2017). Kebayoran Baru dalam Angka. https://doi.org/1102001.3171.060

Dębek, M. (2015). What Drives Shopping Mall Attractiveness? Polish Journal of Applied Psychology. https://doi.org/10.1515/pjap-2015-0026

Farchan, Y. (2016). Analisa Sosial Ekonomi Pembangunan Pusat Perbelanjaan Modern ; Studi Kasus Pembangunan Lotte Mall Di Kecamatan Pondok Aren, Tangerang. Universitas Pamulang, 1(01), 1-10.

Fred, W. (2015). Using the TOWS Matrix Developing Strategic Options From an ExternalInternal Analysis. MindTools.

Heffner, K., \& Twardzik, M. (2015). The Impact of Shopping Centers in Rural Areas and Small Towns in the Outer Metropolitan Zone (The Example of the Silesian Voivodeship). European Countryside. https://doi.org/10.1515/euco-2015-0006

Huberman, A., \& Miles, M. (2012). Understanding and Validity in Qualitative Research. In The Qualitative Researcher's Companion. https://doi.org/10.4135/9781412986274.n2

Kotler, P. (2011). Reinventing marketing to manage the environmental imperative. In Journal of Marketing. https://doi.org/10.1509/jmkg.75.4.132

Maulana, N. (2017). The influence of barosok trading system on ethical business behavior in the husbandry sector in West Sumatera. Journal of Advanced Research in Social Sciences and Humanities, 2(2), 131-138. https://doi.org/10.26500/jarssh-02-20170208

Maxwell, J. A., \& Reybold, L. E. (2015). Qualitative Research. In International Encyclopedia of the Social \& Behavioral Sciences: Second Edition. https://doi.org/10.1016/B978-008-097086-8.10558-6

Munawar, A. (2009). ANALISIS DAMPAK LALULINTAS PEMBANGUNAN PUSAT PERBELANJAAN: STUDI KASUS PLAZA AMBARUKMO. Jurnal Sains \&Teknologi Lingkungan. https://doi.org/10.20885/jstl.vol1.iss1.art2

Putra, G. S. A., \& Maulana, N. (2018). Strategi meningkatkan daya saing industri kreatif Indonesia: Studi Kasus Pengembangan Klaster Industri Tamansari Bogor (Vol. 10, Issue 2).

Ravanavar, G. M. (2012). Strategic Formulation Using Tows Matrix - A Case Study. International Journal of Research and Development.

Sekaran, U., \& Bougie, R. (2011). Business Research Methods: A skill-building approach. In Wiley. $\quad$ https://doi.org/http://as.wiley.com/WileyCDA/WileyTitle/productCd111994225X.html\#

Stäbler, S., \& Fischer, M. (2020). When Does Corporate Social Irresponsibility Become News? Evidence from More Than 1,000 Brand Transgressions Across Five Countries. Journal of Marketing, 84(3), 46-67. https://doi.org/10.1177/0022242920911907

Stritch, J. M., Pedersen, M. J., \& Taggart, G. (2017). The Opportunities and Limitations of Using Mechanical Turk (MTURK) in Public Administration and Management Scholarship. International Public Management Journal, 20(3), 489-511. https://doi.org/10.1080/10967494.2016.1276493 
INOBIS: Jurnal Inovasi Bisnis dan Manajemen Indonesia

Vol. 02, No. 03, Bulan Juni 2020

Noveri Maulana, Joshua Michael Hutagalung

Taylor, N., McClintock, W., \& Buckenham, B. (2003). Social impacts of out-of-centre shopping centres on town centres: A New Zealand case study. Impact Assessment and Project Appraisal. https://doi.org/10.3152/147154603781766428

Wahyuni, S. (2019). Qualitative Research Method: Theory and Practice 3rd Edition (3rd ed., Issue 3rd edition). Penerbit Salemba Empat.

Weihrich, H. (1982). The TOWS matrix-A tool for situational analysis. Long Range Planning. https://doi.org/10.1016/0024-6301(82)90120-0 